\title{
The use of qualitative and quantitative polymerase chain reactions for diagnosis of cytomegalovirus infections in bone marrow and kidney transplant recipients
}

\author{
Desenvolvimento e aplicação de PCRs quali-quantitativas para diagnóstico \\ de citomegalovirose em transplantados de rim e medula óssea
}

\author{
Lauro Juliano Marin ${ }^{1}$, Aldo Albuquerque Cunha ${ }^{1}$, Victor Hugo Aquino ${ }^{1}$ \\ and Luiz Tadeu Moraes Figueiredo ${ }^{1}$
}

\begin{abstract}
The purpose of this work was to test a cytomegalovirus qualitative PCR and a semi-quantitative PCRon the determination of CMV load in leukocytes of bone marrow and kidney transplanted (RT) patients. Thirty three BMT and 35 RT patients participated of the study. The DNA was subjected to a qualitative PCR using primers that amplify part of CMV gB gene. CMV load of positive samples was determined by a semi-quantitative PCR using quantified plasmids inserted with part of the gB gene of $\mathrm{CMV}$ as controls. The sensitivity of the test was determined to be 867 plasmid copies/ $\mu \mathrm{g}$ DNA. CMV loads between 2,118 and 72,443 copies/ $\mu \mathrm{g}$ DNA were observed in 12.1\% BMT recipients and between 1,246 and 58,613 copies/ $\mu \mathrm{g}$ DNA in $22.9 \%$ RT recipients. Further studies are necessary to confirm the usefulness of this CMV semi-quantitative PCR in transplanted patients.
\end{abstract}

Key-words: CMV infection. Qualitative PCR. Quantitative PCR. Bone marrow transplant. Kidney transplant.

\section{RESUM0}

O objetivo deste trabalho foi testar uma PCR qualitativa e uma PCR semiquantitativa para CMV para determinar a carga de CMVnos leucócitos de pacientes transplantados de medula óssea e transplantados de rim. Trinta e três pacientes TMO e 35 TR participaram deste estudo. O DNA foi testado pela PCR qualitativa utilizando primers que amplificam parte do gene gB de CMV. As cargas de CMV das amostras positivas foram determinadas pela PCR semi-quantitativa utilizando como controle plasmídios quantificáveis inseridos com parte do gene gB de CMV. A sensibilidade do teste foi de 867 plamídios/ $\mu \mathrm{g}$ DNA. Cargas de CMV entre 2.118 e 72.443 copias/ $\mu$ g DNAforam observadas em 12,1\% dos TMO entre 1,246 e 58,613 cópias/ $\mu \mathrm{g}$ DNA foram observadas em 22,9\% dos TR. Futuros estudos, com maiores casuísticas são necessários para confirmar a utilidade desta PCR semiquantitativa para CMV em pacientes transplantados.

Palavras-chaves: Infecção por CMV. PCR qualitativa. PCR quantitativa. Transplantados de medula óssea. Transplantados de rim.

Human cytomegaloviruses (CMVs) are members of the betaherpesvirus subfamily of the Herpesviridae family. The virion, measuring between 150 and $200 \mathrm{~nm}$ in diameter, has a lipid bilayer envelope, an icosahedral capsid surrounded by a proteic matrix, and a genome composed of a double stranded linear DNA. Citomegalovirus genome of approximately 240 kilobases, includes more than 200 genes, encoding at least 35 structural proteins and a still undefined number of non structural proteins ${ }^{18}$. The viral envelope is composed of at least eight glycoproteins; most of the neutralizing antibodies are directed against glycoprotein $\mathrm{B}(\mathrm{gB})$ and glycoprotein $\mathrm{H}(\mathrm{gH})^{7}$.

1. Unidade Multidepartamental de Pesquisa em Virologia, Faculdade de Medicina de Ribeirão Preto, Universidade de São Paulo, Ribeirão Preto, SP, Brasil. Research Supported by FAPESP (826/99)

Address to: Prof. Luiz Tadeu Moraes Figueiredo. Unidade Multidepartamental de Pesquisa em Virologia/FMRP/USP. Av. Bandeirantes 3900, 14049-900 Ribeirão Preto, SP, Brasil.

Fax: 16 633-6695, Tel: 16 602-3067

e-mail: ltmfigue@ fmrp.usp.br

Recebido para publicação em 15/1/2003

Aceito em 16/2/2004 
Organ and bone marrow transplant recipients may be infected with CMV by personal contact with the medical care staff, by medical procedures such as hemodialysis, blood transfusions, or by the transplanted organs ${ }^{17}$.

After the infection, CMV stays latent inside several cell types or, eventually, may produce disease. Reactivation of latent CMV infection may occur in periods of decreasing cellular immune response as observed in diseases such as AIDS, or under immunosuppressive therapies such as those used after solid organ and bone marrow transplantation ${ }^{1219}$.

Signs and symptoms of CMV disease include fever, interstitial pneumonia, gastrointestinal manifestations, retinitis, pancytopenia, leukopenia, thrombocytopenia, atypical lymphocytosis, myalgia, splenomegaly and arthralgia ${ }^{8}$. CMV disease in solid organs and bone marrow transplant recipients usually occurs one to four months after transplantation ${ }^{9}$. CMV can also produce immunodepression that could augment opportunistic infections or episodes of graft rejection ${ }^{16}$. Superinfections occur when the patients become infected with a new virus genotype. A study done in Ribeirão Preto, SP, Brazil, showed that $70.6 \%$ of the kidney transplant recipients presented super-infection by CMV ${ }^{1}$.

Active CMV infection can be detected by virus isolation using human fibroblastcell cultures, and the virus identification can be done with specific monoclonal antibodies in immunofluorescent or immunoperoxidase tests ${ }^{20}$. During the last decade, CMV DNA detection by PCR and virus genome nucleotide sequencing have been used for diagnosis and virus strain analysis in transplant patients. Several studies using the PCR for CMV diagnosis in kidney transplant recipients have been reported in Brazil. Aquino \& Figueired $0^{1}$ observed that $100 \%$ of the patients were infected with CMV before renal transplantation. Costa et $\mathrm{al}^{10}$, detecting CMV genome in the urine, observed that $48 \%$ of the renal transplant recipients presented CMV infection and some of these presented clinical manifestations. Caballero etal ${ }^{6}$, found a low incidence of clinical manifestations (8.8\%) in CMV infected patients. These studies show that CMV infections are highly prevalent among Brazilian transplantrecipients, and that a fraction of them present clinical manifestations related to CMV. Therefore, a proper diagnosis of CMV disease is important for an appropriate management of transplant recipients.

This work aimed to evaluate the usefulness of a qualitative PCR and a simple and low cost semi-quantitative PCR for CMV diagnosis in kidney and bone marrow transplant patients.

\section{MATERIAL AND METHODS}

Patients. Thirty-three bone marrow transplant (BMT) recipients attended at the Bone Marrow Transplant Unit of the General Hospital of the Medical School of Ribeirão Preto, University of São Paulo, between 1999 and 2000, participated in the study. These were 18 males and 15 females, aged between 3 and 40 years. Blood samples of the BMT patients presenting more than 1000 leukocytes $/ \mathrm{mm}^{3}$ were collected twice a month, for 4 months after the transplantation. A total of 144 blood samples were collected from BMT group patients. Some BMT patients died immediately after transplantation and it was not possible to collect more than one sample.

Thirty-five renal transplant patients ( RT) managed in the Renal Transplant Unit of the General Hospital of the Medical School of Ribeirão Preto, University of São Paulo, between 1996 and 1997, participated in the study. These were 22 males and 13 females, aged between 21 and 73 years old. Blood samples from RT group patients were collected before transplantation and twice a month during 4 months after transplantation. A total of 265 blood samples were obtained from RT patients. Some RT patients died immediately after transplantation and it was not possible to collect more than one or two samples.

Personal and clinical data were collected from the transplant patient files. Fever associated to pneumonia was considered a clinical manifestation potentially associated to CMV infection. However, though presentin the BMT group of patients, diagnosis could not be confirmed by the detection of CMV antigens in blood leukocytes ${ }^{11}$. For the RT group, fever associated to hepatosplenomegaly or pneumonia was observed in some participants. These clinical manifestations were also considered as potentially associated to CMV infection despite absence of confirmation by CMV antigens detection in blood ${ }^{11}$. Graft rejection in the RT patients was also analyzed regarding results of qualitative and semi-quantitative PCRs for CMV.

Detection of CMV antigens in blood leukocytes from BMT patients was carried out in the laboratory of Dr. Claudio Pannuti at the Institute for Tropical Medicine of the University of São Paulo, in São Paulo. Detection of CMV antigens in blood leukocytes was not done in the RT patients because samples were originally collected just for a CMV genotyping study and only three years later were selected for the present study.

This research project was approved by the Ethic Board of the General Hospital of the Medical School of Ribeirão Preto, University of São Paulo (Process 826/99) .

CMV DNA purification. Five $\mathrm{ml}$ of blood was collected in tubes containing EDTAas anticoagulant. Peripheral blood leukocytes (PBL) were separated by centrifugation in a dextran solution ( Sigma, Germany). The pelletcontaining the PBLs was suspended in 200 $\mathrm{pl}$ of PBS and the DNA was extracted using the QIAamp DNA Blood Kit (Qiagen, Germany), following the manufacturer's recommendation. CMVDNA was also obtained from the supernatant of fibroblastcell cultures infected with CMV AD169 strain using the QIAamp DNA Blood Kit ( Qiagen, Germany) .

Qualitative PCR and nested-PCR for CMV. The reaction mixture of the qualitative PCR contained, in a total volume of $50 \mathrm{\mu l}, 75 \mathrm{mM}$ of Tris- $\mathrm{HCl}(\mathrm{pH} 9), 2 \mathrm{mM}$ of $\mathrm{MgCl}_{2}$, $50 \mathrm{mM}$ of KCl, $20 \mathrm{mM}$ of $\left(\mathrm{NH}_{4}\right) 2 \mathrm{SO}_{4}, 50 \mu \mathrm{M}$ of each one of the deoxynucleoside triphosphates, $0.3 \mu \mathrm{M}$ of primers $\mathrm{gB} 1$ and $g \mathrm{~B} 2$ (as shown in Table 1), and 1 $\mu$ g of DNA obtained from PBLs. The reaction mixture was first incubated at $94^{\circ} \mathrm{C}$ for $3 \mathrm{~min}$, the temperature was then reduced to $80^{\circ} \mathrm{C}$, and $2 \mathrm{U}$ of Taq DNA polymerase were added. The PCR mixture was subjected to 15 cycles of $60 \mathrm{sec}$ at $94^{\circ} \mathrm{C}, 120 \mathrm{sec}$ at $65^{\circ} \mathrm{C}$, and $120 \mathrm{sec}$ at $72^{\circ} \mathrm{C}$, 
Table 1 - Primers used for the PCR and for the nested-PCR detecting CMV in clinical samples.

\begin{tabular}{lcc}
\hline Primers & Nucleotide sequence & Annealing site in CMV genome \\
\hline GB1 & 5'GAAACGCGCGGCAATCGG & 3' \\
GB2 & 5' TGGAACTGGAACGTTTGGC3' & $81874-81891$ \\
gBn1 & 5'GCGCCGTTGATCCACACACC 3' & 82158 - 82176 \\
gBn2 & 5'TACGCTGCAGTTCACCCCAG 3' & 81960 \\
\hline
\end{tabular}

and to 30 cycles of $60 \mathrm{sec}$ at $94^{\circ} \mathrm{C}, 90 \mathrm{sec}$ at $55^{\circ} \mathrm{C}, 120 \mathrm{sec}$ at $72^{\circ} \mathrm{C}$, and finally to 3 min at $72^{\circ} \mathrm{C}$. Two microliters of this reaction were used in a nested-PCR containing the same components as mentioned above, except for the internal primers gBn1 and gBn2 (as shown in Table 1) ${ }^{2}$. The reaction mixture was first incubated at $94^{\circ} \mathrm{C}$ for $3 \mathrm{~min}$, the temperature was then reduced to $80^{\circ} \mathrm{C}$, and $1 \mathrm{U}$ of Taq DNA polymerase was added. The PCR mixture was subjected to 30 cycles of $60 \mathrm{sec}$ at $94^{\circ} \mathrm{C}, 60 \mathrm{sec}$ at $55^{\circ} \mathrm{C}$, and $60 \mathrm{sec}$ at $72^{\circ} \mathrm{C}$, and finally to $3 \mathrm{~min}$ at $72^{\circ} \mathrm{C}$. PCR and nested-PCR products were subjected to electrophoresis in $2 \%$ agarose gel and the amplicon bands were visualized by UV after ethidium bromide staining.

Each PCR assay included a positive control with CMVAD169 DNA and a negative control containing distilled water. PCR for $\beta$-globin gene detection was performed in order to confirm the integrity of the DNA extracts.

Cloning a fragment of the gB gene of CMV into a pCR2.1 plasmid. The amplicon of $296 \mathrm{bp}$ obtained from the CMV $\mathrm{AD} 169 \mathrm{DNA}$ in the PCR using the primers $\mathrm{gB} 1$ and $g \mathrm{~B} 2$ was fused into the plasmid vector pCR2.1 (Invitrogen, USA). The plasmids were amplified in bacteria ( Escherichia coli) and purified with the Plasmid Mini Kit ( Qiagen, Germany). The plasmids were sequenced with the Thermo Sequenase CY5.5 terminator kit (Amersham, England), using the M13/Forward-Reverse primers. The sequencing reaction was resolved in an automated sequencer ( Seq $4 \mathrm{x} 4$, Pharmacia, USA). The obtained sequence was compared with that of the CMVAD169 strain (Genbank, seqüence M60931) using the DNAsis software ( Hitachi, Japan).

Plasmid quantification. The molecular weight of the plasmid containing the insert of $296 \mathrm{bp}$ was calculated considering as 660 the average molecular weight of a base pair and was found to be 1400190 . Therefore, $1400190 \mathrm{~g}$ of the plasmid contain $6.02 \times 10^{23}$ plasmid molecules (Avogrado's number). Thus, the number of plasmid particles in our stock solution was determined based on the plasmid DNA concentration obtained by spectrophotometry at $260 \mathrm{~nm}$. Aliquots of the quantified plasmid were stored at $-20^{\circ} \mathrm{C}$ until use for the CMV semi-quantitative PCR tests.

Sensitivity of the CMV semi-quantitative PCR. The sensitivity of the CMV semi-quantitative PCR using primers gB1 and $g B 2$ was determined by testing, in quadruplicate, decimal dilutions of the cloned plasmid solution. Specific amplicons with $296 \mathrm{bp}$ were detected until the $10^{-8}$-fold dilution, which corresponds to 867 plasmids, as shown in Figure 1.

CMV semi-quantitative PCR. CMV load was determined in all clinical samples with a positive result in the qualitative PCR. The protocol used in the semi-quantitative PCR was the same as that used in the qualitative PCR, except for the addition

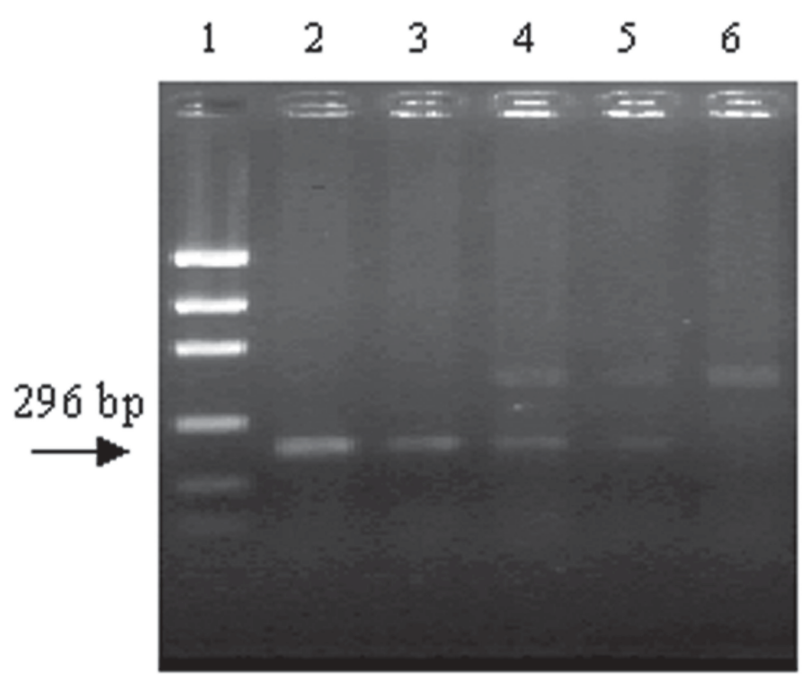

Figure 1 - Agarose gel stained with ethidium bromide showing, under UV light, amplicons obtained from decimal dilutions of the $\mathrm{gB} \mathrm{CMV}$ cloned plasmid by using the CMV semi-quantitative PCR: column 1 shows the 100bp DNA ladder; column 2 shows a 296 bp amplicon band from a 867000 plasmid solution; column 3 shows amplicon band from a 86700 plasmid solution, column 4 , shows amplicon band from a 8670 plasmid solution; column 5, shows a weak amplicon band from a 867 plasmid solution (limit detection of the test); and column 6 from a 86 plasmid solution, does not show any amplicon band.

of 2.5U of Taq DNA polymerase and $1 \mu \mathrm{g}$ of the clinical sample DNA. For the semi-quantitative PCR, samples containing 80000,8000 , 800 and 80 plasmid particles were tested simultaneously with the clinical samples. The PCR products were subjected to electrophoresis in $2 \%$ agarose gel and the amplicons were visualized by UV light and photographed with the Science 1D digital came (Kodak, USA). The amplicon band densities were determined using the DC120 Digital Access software (Kodak, USA).

The CMV load of the clinical samples was determined by plotting the amplicon band density value of each sample into a graphic including samples containing 80000, 8000, 800 and 80 plasmid particles, as shown in Figure 2.

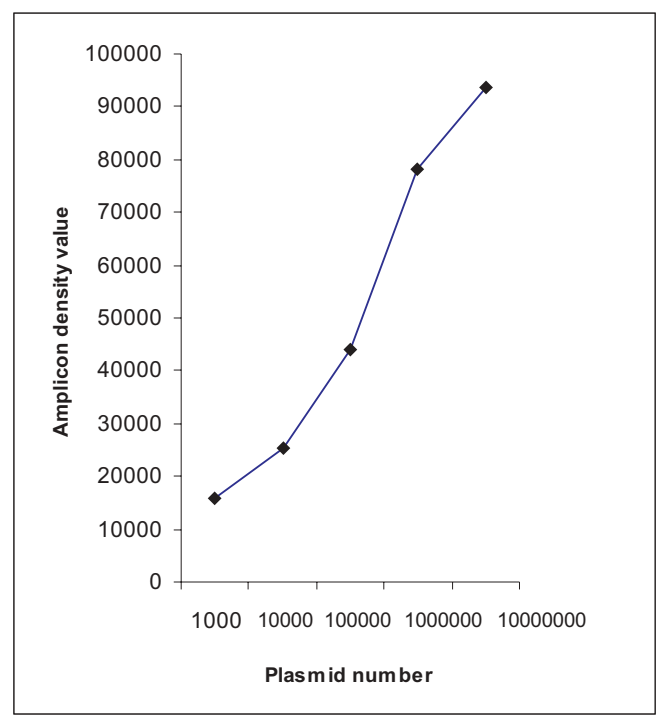

Figure 2 - Graphic of density values of amplicon bands obtained from 867, 8670, 86700, 867000, $8670000 \mathrm{gB} \mathrm{CMV}$ plasmids in the semi-quantitative PCR. 
Statistical analysis. Personal and clinical data as well as laboratory test results were confronted to results of the CMV qualitative amplification and with the semi-quantitative PCR tests by using the Chi-square and the Fisher's exact test $(p<0.05)$.

\section{RESULTS}

CMV qualitative PCR. One hundred forty four blood samples from 33 BMT patients were tested by the CMV qualitative PCR, and the CMV genome was detected in 16 (11.1\%) samples belonging to nine (27.3\%) patients. Likewise, 265 blood samples from 35 RT patients were tested by the CMV qualitative PCR, and the CMV genome was detected in 23 (8.7\%) samples belonging to $13(37.1 \%)$ patients. All these positive results were confirmed by nested-PCR.

CMV semi-quantitative PCR. CMV DNA load was determined in those samples having CMV genome detected by qualitative PCR. Four (25\%) samples belonging to four (44.4\%) BMT patients showed CMV loads between 2118 and 72443 virus particles/ $\mu \mathrm{g}$ DNA. Thirteen (25\%) samples belonging to eight (61.5\%) RT patients showed CMVloads between 1246 and 58613 virus particles/ $\mu \mathrm{g}$ DNA.

Association analysis of personal and clinical data from BMT and RT patients with results of CMV qualitative and semi-quantitative PCRs. Personal, clinical data and CMV loads from BMT and RT patients having CMV genome detected by qualitative PCR are shown in Tables 2 and 3 , respectively. Personal and clinical data of these patients were compared with those of the remaining 24 BMT patients and the 22 RT patients who did not have CMV genome detected. No association of positive qualitative PCR with personal and clinical data of the BMT and RT patients was observed. However, BMT patients having CMV loads higher than $10000 \mathrm{CMV}$ particles/ $\mu \mathrm{g}$ DNA showed $100 \%$ specificity and $100 \%$ positive predictive value regarding fever and pneumonia, as well as 70.8\% sensitivity. The negative predictive value was low, $22.2 \%$. Corroborating this association, BMT patients having the highest CMV loads ( 63095 and 72443 particles/ $\mu$ g DNA) presented fever and pneumonia. Association between CMVload and fever was not observed in RT patients, including those with more than $10000 \mathrm{CMV}$ particles/ $\mu \mathrm{g}$ DNA. Likewise, association of graft rejection with CMV genome detection was not observed in the RT group.

\section{DISCUSSION}

PCR has been commonly used for diagnosis of CMV infections showing a higher sensitivity when compared to virus isolation in tissue culture and to antigenemia detection. $\mathrm{CMV}$ is also detected earlier by PCR than by other techniques ${ }^{26}$. Other advantages of the PCR include simplicity, requires small quantities of clinical samples, and the use of stored samples.

The qualitative PCR for CMV genome detection followed by confirmatory nested-PCR with gB primers has been used in our laboratory for processing urine, blood, saliva, milk and other secretion samples, showing high sensitivity and specificity. These sensitivity and specificity rates are higher than those reported for CMV serologic tests ${ }^{25}$. The CMV genome detection by qualitative PCR followed by confirmatory nested-PCR with $\mathrm{gB}$ primers, processing urine and blood samples of kidney transplant patients, was able to detect $94.3 \%$ of active CMV infections during a 3 to 10-month follow-up period ${ }^{2}$. In the

Table 2 - Personal and clinical data also including CMV loads (bold type) from the 9 BMT patients having CMV genome detected by qualitative PCR.

\begin{tabular}{|c|c|c|c|c|c|c|c|c|c|c|}
\hline Patient Sample & Age & Sex & Disease & Donor & $\begin{array}{c}\text { Date of } \\
\text { transplant }\end{array}$ & $\begin{array}{c}\text { Date } \\
\text { of sample }\end{array}$ & 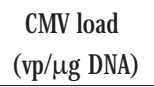 & Antig & Cinical aspect & Outcome \\
\hline $3 ; 2$ & 31 & M & NHL & autologous & 26-04-99 & +32 & $<867$ & neg & fever & death \\
\hline $3 ; 3$ & & & & & & +43 & $<867$ & neg & & \\
\hline $4 ; 2$ & 39 & $\mathrm{~F}$ & AML & autologous & $24-06-99$ & +34 & $<867$ & neg & fever & death \\
\hline $4 ; 3$ & & & & & & +45 & 2118 & neg & & \\
\hline $6 ; 1$ & 40 & M & CML & allogenic & 08-06-99 & +30 & 7224 & neg & fever & recovery \\
\hline $6 ; 2$ & & & & & & +49 & $<867$ & neg & & \\
\hline $7 ; 3$ & 3 & $\mathrm{~F}$ & SAA & allogenic & $15-06-99$ & +52 & $<867$ & neg & fever & recovery \\
\hline $7 ; 6$ & & & & & & +101 & $<867$ & neg & & \\
\hline $8 ; 5$ & 19 & M & $\begin{array}{l}\text { Hodgkin's } \\
\text { disease }\end{array}$ & autologous & 01-07-99 & +59 & 63095 & neg & fever, PN & recovery \\
\hline $12 ; 1$ & 22 & $\mathrm{~F}$ & $\begin{array}{c}\text { Hypo-plastic s } \\
\text { yndrome }\end{array}$ & allogenic & $19-08-99$ & +21 & $<867$ & neg & fever, PN & death \\
\hline $21 ; 2$ & 24 & $\mathrm{~F}$ & & & & +45 & $<867$ & 1 cell & & \\
\hline $21 ; 3$ & & & BLA & allogenic & $18-02-00$ & +60 & 72443 & neg & fever, PN & recovery \\
\hline $21 ; 4$ & & & & & & +74 & $<867$ & neg & & \\
\hline $21 ; 5$ & & & & & & +102 & $<867$ & neg & & \\
\hline $27 ; 5$ & 29 & M & $\mathrm{CML}$ & allogenic & $14-07-00$ & +97 & $<867$ & neg & fever, PN & death \\
\hline $28 ; 3$ & 26 & $\mathrm{~F}$ & Hodgkin's disease & autologous & $10-07-00$ & +57 & $<867$ & neg & fever & recovery \\
\hline
\end{tabular}

Antig = CMV antigen detection in blood leukocytes, NHL = Non Hodgkin's lymphoma BLA = biphenotypic acute leukemia, AML = acute myeloid leukemia, CML = chronic myeloid leukemia, $\mathrm{SAA}=$ severe aplastic anemia, $\mathrm{PN}=$ pneumonia, $\mathrm{M}=$ male, $\mathrm{F}=$ female, Neg = negative test. 
Table 3 - Personal and clinical data also including CMVloads (bold) from the 13 RT patients having CMV genome detected by qualitative PCR.

\begin{tabular}{|c|c|c|c|c|c|c|c|c|c|}
\hline $\begin{array}{l}\text { Patient } \\
\text { Sample }\end{array}$ & Age & Sex & Donor & $\begin{array}{c}\text { Date of } \\
\text { transplant }\end{array}$ & $\begin{array}{l}\text { Date of } \\
\text { sample }\end{array}$ & $\begin{array}{c}\text { CMV load } \\
\text { (pv/ug DNA) }\end{array}$ & $\begin{array}{l}\text { Clinical } \\
\text { aspect }\end{array}$ & $\begin{array}{l}\text { crisis of } \\
\text { Rejection }\end{array}$ & Outcome \\
\hline $9 ; 4$ & 23 & $\mathrm{M}$ & cadaver & $30-11-96$ & +34 & 58210 & fever, PN & yes & nephrectomy \\
\hline $9 ; 6$ & & & & & & & +48 & 1931 & \\
\hline $9 ; 7$ & & & & & & & +55 & 4920 & \\
\hline $11 ; 9$ & 70 & M & cadaver & $20-11-96$ & +296 & $<867$ & no & no & RKG \\
\hline $13 ; 6$ & 27 & $\mathrm{~F}$ & cadaver & $11-12-96$ & +37 & $<867$ & fever, PN & yes & RKG \\
\hline $15 ; 3$ & & & & & & & +15 & 4786 & \\
\hline $15 ; 4$ & & & & & & & +22 & 3435 & \\
\hline $15 ; 5$ & 48 & M & cadaver & 26-03-97 & +29 & 22803 & no & no & RKG \\
\hline $15 ; 6$ & & & & & & & +35 & $<867$ & \\
\hline $15 ; 7$ & & & & & & & +111 & $<867$ & \\
\hline $15 ; 8$ & & & & & & & +154 & $<867$ & \\
\hline $16 ; 4$ & 51 & F & cadaver & 27-3-97 & +28 & $<867$ & no & yes & RKG \\
\hline $16 ; 5$ & & & & & & & +41 & $<867$ & \\
\hline $19 ; 3$ & 62 & $\mathrm{~F}$ & cadaver & 06-06-97 & +40 & $<867$ & no & no & RKG \\
\hline $20 ; 3$ & 43 & $\mathrm{~F}$ & cadaver & 28-06-97 & +26 & $<867$ & no & yes & nephrectomy \\
\hline $20 ; 4$ & & & & & & & +40 & 26121 & \\
\hline $21 ; 5$ & 33 & M & cadaver & $30-06-97$ & +38 & 1246 & no & yes & RKG \\
\hline $24 ; 8$ & 41 & M & cadaver & 20-06-97 & +173 & $<867$ & no & no & RKG \\
\hline $25 ; 4$ & 41 & M & cadaver & 20-06-97 & +62 & 5571 & no & no & RKG \\
\hline $27 ; 8$ & 35 & $\mathrm{M}$ & cadaver & 13-08-97 & +105 & 49317 & fever & yes & nephrectomy \\
\hline $29 ; 4$ & 18 & $\mathrm{~F}$ & cadaver & 05-09-97 & +33 & 58613 & no & no & RKG \\
\hline $29 ; 5$ & & & & & & & +54 & 39810 & \\
\hline $31 ; 5$ & 52 & M & cadaver & 28-09-97 & +45 & 3741 & no & no & RKG \\
\hline
\end{tabular}

present study, CMV qualitative and semi-quantitative PCRs were performed using DNA extracts from PBL. These cells were selected because during CMV infection, blood leukocytes participate in virus spreading into different organs and these cells are known as preferential sites for viral replication specially in immunocompromised hosts and latency ${ }^{22}$.

Aproportion of $27.3 \%$ of the BMT patients had CMV genome detected by qualitative PCR. This result is similar to thatreported by Woo et $\mathrm{al}^{24}$, who detected CMV by PCR in $34.1 \%$ of bone marrow transplant patients. The positivity rate of CMV qualitative PCR was higher than that of antigenemia. Only one of the BMT patients having CMV genome detected by qualitative PCR had CMV pp65 detected in PBLs. This low positive rate of CMV antigenemia suggests that only a small number of the BMT patients had active CMV infection or disease. Our results, as reported by other authors, show that genome detection by PCR is more sensitive than antigen detection in PBLs for CMV diagnosis ${ }^{3}$. Considering that some patients having fever, pneumonia, and virus genome detected by PCR were negative for antigen detection in PBLs, highly suggestive evidences of CMV disease, this low sensitivity antigenemia should not be considered a suitable method for diagnosis of CMV active infection or disease. Likewise it should not be considered a suitable method for use as the gold standard in the present study.

Among RT patients, 37.1\% had CMV genome detected by qualitative PCR. Likewise, 23\% of these patients presented fever, a clinical manifestation that could be associated to CMV disease. A higher positive rate of CMV genome detection (63.1\%) was reported by Mas et a ${ }^{15}$, studying PBLs of 65 renal transplant patients, although only $19.5 \%$ of the studied patients had

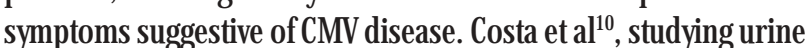
of 37 kidney transplant patients by PCR, observed CMV genome detection in $64.9 \%$ of the patients, $43.2 \%$ of these with symptoms suggestive of CMV disease. However, only three patients were confirmed as having CMV disease based on the presence of virus in bronchoalveolar secretions or by lung histopathology. In the study by Costa et al ${ }^{10}$, most of these reported symptoms were probably caused by other etiologic agents.

The detection of CMV genome in about $1 / 3$ of both BMT and RT patients, shows that the qualitative PCR test with gB primers is a suitable technique for screening CMV infections in transplanted patients. However, CMV qualitative PCRs were not suitable to discriminate latent or active CMV infections. Other studies of immunocompromised patients show a positive correlation between CMVload and active infection or disease ${ }^{3}$. Some of these studies have demonstrated an association between high CMV viremias and clinical manifestations or increased risk of CMV disease $e^{4}$. In the last five years, several CMV semi-quantitative and quantitative diagnostic techniques were reported ${ }^{3}$. However, in spite of their high sensitivity, these techniques are expensive, which impedes its routine use in third world countries, such as Brazil. In the presentwork, we evaluated the usefulness of a low costand easily handled CMV semi-quantitative PCR technique for CMV diagnosis of active infections and disease. This CMV semi-quantitative PCR technique uses gB CMV cloned plasmids obtained in our laboratory as positive controls.

The absence of a suitable gold standard technique for comparison with PCR for the diagnosis of CMV active infection and CMV disease is a limitation of the present study ${ }^{3}$. Likewise, 
despite of many reported CMV quantitative PCR techniques, the comparison of these techniques with ours is difficult because they were used for processing different kinds of clinical samples such as plasma, whole blood, or urine ${ }^{1314}$. Furthermore, some authors who used leukocyte samples for quantification of CMV also showed unsuitable results for comparison due to very different sensitivities. Toyoda et a ${ }^{21}$ described a highly sensitive technique, able to detect five virus particles/ $\mu \mathrm{g}$ DNA. Caballero et $\mathrm{al}^{5}$, described a CMV semi-quantitative PCR having a similar sensitivity to that of the present work, 800 virus particles/ $\mu$ g DNA. We suppose that the sensitivity of our CMV semi-quantitative PCR technique, 867 virus particles/ $\mu \mathrm{gDNA}$, is suitable for the diagnosis ofCMV active infection and disease based on the need of viral replication and high viral loads for the expression of these manifestations ${ }^{3}$.

Viral loads of 2118 to 72443 virus particles/ $\mu \mathrm{g}$ DNA were detected in the BMT patients by using the CMV semi-quantitative PCR. These patients corresponded to $44.4 \%$ of those having CMV genome detected by the qualitative PCR. The BMT patients presenting the highest CMV loads ( 63095 and 72443 virus particles/ $\mu \mathrm{g}$ DNA) also presented fever and pneumonia. An association with presence of fever and pneumonia, despite not being confirmed as CMV disease, was investigated in two BMT patients with a CMV load higher than 10000 particles/ $\mu \mathrm{g}$ DNA, showing $100 \%$ specificity and $100 \%$ positive predictive value.

All the samples of RT that had CMV detected by the qualitative test, were subjected to CMV semi-quantitative PCR. CMV loads above 867 particles/ $\mu$ g DNA were observed in $61.5 \%$ of the samples. CMV loads between 1246 and 58613 virus particles/ $\mu \mathrm{g}$ DNA were observed. No association between CMVloads, including specifically those higher than 10000 particles/ $\mu \mathrm{g}$ DNA, with presence of fever was observed among the RT patients. Our results are in agreement with those reported by other authors. Toyoda et $\mathrm{al}^{21}$, studying 25 kidney transplanted and 95 heart transplanted patients during three years, showed that patients having $500 \mathrm{CMV}$ particles/ $\mu \mathrm{g}$ DNA did not present symptoms suggestive of CMV disease while other patients with 50 to $100 \mathrm{CMV}$ particles/ $\mu \mathrm{g}$ DNA presented these clinical symptoms.

Graft rejection crisis in the RT patients was not associated with CMV loads. Nevertheless, kidney graft rejection crisis could be explained by many other causes not associated with CMV infections.

In short, qualitative PCR followed by confirmatory nested$\mathrm{PCR}$ with $\mathrm{gB}$ primers allowed the screening of CMV infections in BMT and RT patients. The CMV genome was detected in an expressive amount of patients. However, qualitative PCR was not able either to diagnose or to discriminate CMV active infection from disease. Our semi-quantitative PCR was able to detect CMV loads above 867 particles/ $\mu$ g DNA in 4 BMT and 9 RT patients suggesting that these were cases of active infection; this is a necessary condition for CMV disease. One hundred percent specificity and 100\% positive predictive value for fever and pneumonia was observed among BMT patients having high CMV loads (more than 10000 viral particles/ $\mu$ g DNA). High CMV loads were also observed in five RT patients but a significant association of high CMV load with the presence of clinical manifestations suggestive of CMV disease among them was not observed. We suppose that only a small number of the transplant recipients that participated in the present study had CMV disease. However, it is possible that CMV was the etiological agent of the clinical manifestations in the two BMT patients having high CMV load. We conclude that the studied population did not allow a definitive opinion on the usefulness of our CMV semi-quantitative PCR for the diagnosis of CMV disease in BMT and in RT patients. Further studies are necessary in order to confirm the usefulness of this CMV semi-quantitative PCR in transplanted patients.

\section{REFERENCES}

1. Aquino VH, Figueiredo LTM. High prevalence of renal transplant recipients infected with more than one cytomegalovirus glycoprotein B genotype. Journal of Medical Virology 61: 138-142, 2000.

2. Aquino VH, Figueiredo LTM. Cytomegalovirus infection in renal transplant recipients diagnosed by nested-PCR. Brazilian Journal of Medical Biological Research 34: 93-101, 2001.

3. Boeckh M, Boivin G. Quantitation of cytomegalovirus: Methodologic aspects and clinical applications. Clinical Microbiology Reviews 11: 533-554, 1998.

4. Bowen EF, Sabin CA, Wilson P, Grifftiths PD, Davey CC, Johnson MA, Emery VC. Cytomegalovirus ( CMV) viraemia detected by polymerase chain reaction identifies a group of HIV positive patients at high risk of CMV disease. Aids 11: 889-893, 1997.

5. Caballero OL, Costa MCSL, Trevisan A, Oliveira RM, Viotti EA, Távora ERF, Vilaça, SS, Sabagga E, De-paula FJ, Távora PF, Villa LL, Simpson AJG. Monitoring human cytomegalovirus viral load in peripheral blood leukocytes of renal transplant recipients by a simple PCR limiting dilution. Brazilian Journal of Medical Biological Research 32: 1515-1523, 1999.

6. Caballero OL, Menezes CL, Costa MC, Fernandes SC, Anacleto TA, Oliveira RM, Viotti EA, Tavora ER, Vilaça SS, Sabbaga E, Paula F, Tavora PF, Villa LL, Simpson AJG. Highly sensitive single-step PCR protocol for diagnosis and monitoring of human cytomegalovirus infection in renal transplant recipients. Journal Clinical Microbiology 35: 3192-3197, 1997.

7. Chee MS, Bankier AT, Beck S, Bohni R, Brown CM, Cerny R, Horsnell T, Hutchison CA, Kouzarides R, Martignetti JA. Analysis of the protein-coding content of the sequence of human cytomegalovirus strain AD 169. Current Topics in Microbiology and Immunology 154:125-169, 1990.

8. Chou S, Norman DJ. Effect of OKT3 antibody therapy on cytomegalovirus reactivation in renal transplant recipients. Transplantation Procedures 17: 2755-2756, 1985

9. Costa SCB. Infecção por Citomegalovirus (CMV) : Epidemiologia, Diagnóstico e Tratamento. Revista Brasileira de Clínica e Terapêutica 25:18-28, 1999.

10. Costa SCB, Miranda SRP, Alves G, Rossi CL, Figueiredo LTM, Costa FF. Donated organs as a source of cytomegalovirus (CMV) in renal transplant patients. Brazilian Journal of Medical and Biological Research 27: 2573-2578, 1994.

11. Crumpacker CS. Cytomegalovirus. In: Mandell, Douglas, Bennett's (eds) Principles and Practice of Infectious Diseases. Fifth edition, Churchill Livingstone, USA, v.2, p.1586-1587, 2000.

12. Drummer JS. Cytomegalovirus infection after liver transplantation: clinical manifestation and strategies for prevention. Reviews of Infectious Diseases 12: 767-775, 1990.

13. Gor D, Sabin C, Prentice HG, Yyas N, Man S, Griffith PD, Emery VC. Longitudinal fluctuation in cytomegalovirus load in bone marrow transplant patients: relationship between peak virus load, donor/recipient seostatus??, acute GVHD and CMV disease. Bone Marrow Transplantation 21: 597-605, 1998.

14. Humar A, Gregson D, Caliendo AM, Mcgeer A, Malkan G, Krajden M, Corey P, Greig P Walmsley S, Levy G, Mazzulli T. Clinical utility of quantitative 
cytomegalovirus viral load determination for predicting cytomegalovirus disease in liver transplant recipients. Transplantation 68: 1305-1311, 1999.

15. Mas V, Alvarellos T, Albano S, Boccardo G, Giraudo C, Ferreira-gonzales A. Utility of cytomegalovirus viral load in renal transplant patients in Argentina. Transplantation 67: 1050-1055, 1999.

16. Maya TC, Azulay DR. Infecção pelo citomegalovirus. In: Lupi 0, Silva AS, Pereira Jr AC. Medsi Editora Médica e Científica Ltda, (eds) Herpes-Clínica Diagnóstico e Tratamento, $1^{\circ}$ edição, cap.8: p.135-156, 2000.

17. Meyers JD, Flournoy N, Thomas ED, Risk factors for cytomegalovirus infection after human marrow transplantation. Journal of Infectious Disease 153: 478-488, 1986

18. Mocarski Jr ES. Cytomegalovirus and their replication. In: Fields, Knipe DM, Howley PM ( eds) Fields Virology. Raven Publishers, Philadelphia, Cap. 76: p.2447-2492. 1996.

19. Quinnam GV, Burns WH, Kirmani N, Rook AH, Manischewitz JF, Jackson L, Santos GW, Saral R. HLA restricted cytotoxic T lymphocytes are early immune response and important defense mechanism in cytomegalovirus infection. Reviews of Infectious Diseases 6: 156-163, 1984.

20. Suassuna JHR, Machado RD. Diagnóstico das infecções por citomegalovirus em pacientes com deficiência imunológica. Revista da Associação Médica Brasileira 38: 33-47, 1992.
21. Toyoda M, Carlos JB, Galera OA, Galfayan K, Zhang X, Sun Z, Czer LSC, Jordan SC. Correlation of cytomegalovirus DNA levels with response to antiviral therapy in cardiac and renal allograft recipients. Transplantation 63: 957-963, 1997

22. Van der bij W, Torensma R, Van son WJ, Anema J, Schirm J, Tegzess AM, The TH. Rapid immunodiagnosis of active cytomegalovirus infection by monoclonal antibody staining of blood leukocytes. Journal of Medical Virology 25: 179-188, 1988.

23. Weller $\mathrm{TH}$, Hanshaw JB. Virologic and clinical observations on cytomegalic inclusion disease. New England Journal of Medicine 226: 1233-1244, 1962.

24. Woo PCY, Lo SKF, Yuen KY, Peiris JSM, Siau H, Chiu EKW, Liang RHS, Chan TK. Detection of CMV DNA in bone marrow transplant recipients: plasma versus leukocyte polymerase chain reaction. Journal of Clinical Pathology 50: 231 . 235, 1977.

25. Yamamoto AY, Mussi-pinhata MMM, Figueiredo LTM. Prevalência e aspectos clínicos da infecção congênita por citomegalovirus. Jornal de Pediatria 75: 23-28, 1999

26. Yamamoto AY, Pinhata MMM, Pinto PCG, Figueiredo LTM, Jorge SM. Congenital cytomegalovirus infection in preterm and full-term newborn infants from a population with a high seroprevalence rate. The Pediatric Infectious Diseases Journal 20: 188-192, 2001. 